\title{
Cerebrovascular Complications of Neck Manipulation
}

\author{
Adrian B. Wenban \\ Australian Spinal Research Foundation, Springwood, Qld., Australia; Fundación Privada Quiropráctica, Barcelona, \\ Spain
}

Dear Sir,

I read with interest the review by $\mathrm{Pa}$ ciaroni and Bogousslavsky [1], titled 'Cerebrovascular Complications of Neck Manipulation', in your February 2009 edition. I would like to thank the authors for what, overall, I found to be quite a balanced and fair review and subsequent discussion of the literature relevant to this subject.

One aspect of the authors' review does, however, concern me. I suspect that the search strategy which the authors used in collecting data for their review may, to some extent, have biased their findings. Specifically, I am concerned that although the authors note in their introduction that 'In fact, it [spinal manipulation] is commonly used by osteopaths, physiothera- pists and physicians and is the hallmark treatment of manual therapists', their search strategy included both the terms 'manual therapy' and 'chiropractic', but did not include either 'physiotherapy', 'osteopathy' or the word 'physician'.

Additionally, the only key word listed by the authors which is associated with any one profession was 'chiropractic therapy'.

In all fairness, if, as the authors state, spinal manipulation is commonly used by osteopaths, physiotherapists and physicians and is the hallmark treatment of manual therapists, should not reference to those professions also be included in the review's search strategy?
Again, I thank the authors for their contribution and look forward to their response.

\section{Conflict of Interest}

The author is a chiropractor, in parttime practice, and is the Director of the Barcelona College of Chiropractic.

\section{Reference}

1 Paciaroni M, Bogousslavsky J: Cerebrovascular complications of neck manipulation. Eur Neurol 2009;61:112-118.

\section{Reply}

Dear Dr. Wenban,

Thank you for your kind interest in our review article. Concerning your opinion that spinal manipulation should reference professions including osteopaths, physiotherapists as well as physicians, you are right in stating that there might be a bias in the selection of the papers. Unfortunately, during our thorough in- vestigation we came across only a limited number of acceptable works to include in the study. This is because in the literature, currently there are no valid studies dealing with this topic from all professions' points of view.

Maurizio Paciaroni, Julien Bogousslavsky

\section{KARGER \\ Fax +41613061234 E-Mail karger@karger.ch} www.karger.com
(C) 2010 S. Karger AG, Basel

$0014-3022 / 10 / 0634-0248 \$ 26.00 / 0$

Accessible online at:

www.karger.com/ene
Adrian B. Wenban, BSc, BAppSc, MMedSc, MACC

Calle Mallorca $364,2^{\circ} 1^{\mathrm{a}}$

ES-8013 Barcelona (Spain)

Tel./Fax +349330 27570, E-Mail adrianwenban@gmail.com 